\title{
Genotyping of hepatitis B virus from dried and stored serum on filter paper
}

\author{
Rino A Gani, A.D. Handayu, Reny Mulatsih, L.A. Lesmana, Ali Sulaiman, Nurul Akbar
}

\begin{abstract}
Abstrak
Genotipe virus hepatitis B (VHB) mempunyai hubungan yang erat dengan prognosis dan terapinya serta diperlukan untuk studi epidemiologi. Pemeriksaan ini hanya bisa dikerjakan di kota-kota besar saja karena kesulitan pengiriman sampel akibat masalah geografis maupun fasilitas. Tujuan penelitian ini adalah untuk mengetahui apakah genotipe VHB dapat ditentukan dari serum kering pada kertas saring dan membandingkan hasil tersebut dengan serum yang diambil langsung dari pasien hepatitis $B$ kronik (HBK) dan hepatoma. Dua puluh tiga sampel dapat diambil dari pasien HBK dan konsentrasi DNA VHB di tentukan dengan Cobas Amplicor HBM (Roche Diagnostics GmBH, Germany) kemudian diteteskan pada kertas saring $(3 \times 1 \mathrm{~cm})$. Setelah dikeringkan dalam kantong plastik, diletakkan dalam amplop tertutup dan disimpan selama 1 minggu dalam suhu kamar $\left(27-33^{\circ} \mathrm{C}\right)$. Ekstraksi DNA dilakukan dari kertas saring tersebut setelah diinkubasi dan penentuan genotipe VHB dilakukan dengan PCR menggunakan primer-primer spesifik. Untuk perbandingan, telah didapatkan 20 sampel pasien $H B K-H B e(+)$ dan 29 sampel pasien hepatoma yang tidak dikeringkan. Genotipe VHB dapat dideteksi pada 18/23 (78,2\%) serum kering pada kertas saring sedangkan pada serum yang tidak dikeringkan, dari pasien $\mathrm{HBK}-\mathrm{HBe}(+)$ 20/20 (100\%) sampel terdeteksi dan dari pasien hepatoma 24/29 (82,7\%) sampel. Proporsi genotipe yang terdeteksi sesuai dengan proporsi genotipe yang pernah dilaporkan di Indonesia. Kesimpulan penelitian ini adalah genotipe VHB dapat dideteksi dari serum kering pada kertas saring yang disimpan selama 1 minggu. (Med J Indones 2005; 14: 215-9)
\end{abstract}

\begin{abstract}
$H B V$ genotype has a close association with prognosis and therapy as well as for epidemiology study. However, this examination can be done only in large cities that are not practical to send serum sample due to geographical burden and facilities. The aim of this study is to know whether HBV genotype can be determined from dried and stored serum on filter paper and compare the result with sera drawn directly from chronic hepatitis $B(C H B)$ and hepatoma patients. Twenty-three serum samples were obtained from $C H B$ patients. HBV DNA were quantitatively determined with Cobas Amplicor HBM (Roche Diagnostics GmBH, Germany) and dropped on to $3 \times 1 \mathrm{~cm}$ filter papers. After allowed to dry in a plastic clip, it were put in a closed envelope then stored for 1 week in room condition $\left(27-33^{\circ} \mathrm{C}\right)$. DNA extraction were done from the filter papers after a short incubation period and HBV genotypes were determined with PCR and specific primers. For comparison, $20 \mathrm{CHB}-\mathrm{Hbe}(+)$ samples and 29 hepatoma samples were drawn directly and not dried. HBV genotype were detected in 18/23 (78.2\%) from dried serum samples on filter paper while in sera that were not stored, from $\mathrm{CHB}-\mathrm{HBe}(+)$ samples, $20 / 20$ (100\%) could be determined while from hepatoma patients, 24/29 (82.7\%) samples. The proportion of genotype were in line with other reported $H B V$ genotype examination for Indonesia. It is concluded that detection of $H B V$ genotype can be done from dried serum in filter paper and stored for 1 week. (Med J Indones 2005; 14: 215-9)
\end{abstract}

Keywords: Hepatitis B virus, genotype, filter paper

Hepatitis $\mathrm{B}$ virus infection is a major problem that may lead to chronic liver inflammation, liver cirrhosis and hepatoma. ${ }^{1}$ HBV infection were prevalent in Asia Pacific countries like Indonesia. Carrier rate from voluntary blood donors were $2.1-9.5 \%$ in 11 large cities in Indonesia. The number were even larger in Jayapura, Irian Jaya that is rose up to $17.5 \%{ }^{2}$

Division of Hepatology Department of Internal Medicine, Faculty of Medicine University of Indonesia / Dr. Cipto Mangunkusumo Hospital, Jakarta, Indonesia
According to nucleotide sequence differences, HBV can be classified in to genotypes A to H. Clinically, HBV genotype may play some role in the natural history and treatment of HBV infection., ${ }^{3,4}$ Genotype of HBV have been shown to have important meaning in epidemiology study. ${ }^{1,5}$ Since HBV were transmitted from mother to child, genotype study may help anthropology study. ${ }^{6}$

However, not all laboratories in Indonesia can perform HBV genotyping, especially in small cities or rural area. The serum samples should be sent to large 
cities in tubes and with careful cold packing to ensure the quality of serum; the effort that can not always be performed in every health centers. This problem are even more difficult in epidemiology study of remote area.

HBV DNA can be detected from dried serum in filter papers. ${ }^{7,8}$ This method can be developed further to make samples transportation more practical that can be used to make identification of HBV genotype. Nevertheless, currently there are no published report on the detection of HBV genotype from stored dried serum on filter paper in order to be sent.

The aim of this study is to know whether HBV genotype can be determined from dried and stored serum on filter paper and compare the results of genotyping with this method to serum that directly drawn from patients.

\section{METHOD}

Serum from patients with chronic hepatitis B were drawn with Vacutainer and aliquot in to 2 ependorf tubes. One part of the serum were used to determined HBV DNA quantitatively with Cobas Amplicore HBM system (Roche Diagnostics, GmBH Germany) and the other part were dropped on to filter papers.

Serum were also taken from chronic hepatitis B with $\mathrm{HBeAg}$ positive and hepatoma patients and stored directly in to a refrigerator $\left(-40^{\circ} \mathrm{C}\right)$ untill it were used. The result of genotyping of these samples would be compared to dried and stored serum.

We used filter paper of Whatman No. 1, cut $3 \times 1 \mathrm{~cm}$ with sterile scissor. Plastic clip for this study was $8 \mathrm{x}$ $5 \mathrm{~cm}$.

HBV DNA in the serum had been quantitated with automated PCR Cobas Amplicor HBM (Roche Diagnostics, GmBH, Germany) that has a linier reading for HBV DNA $3 \times 10^{2}-2 \times 10^{5}$ copy $/ \mathrm{mL}$. This measurement was done to find out the influence of HBV DNA concentration in the serum to sensitivity of genotype detection from dried serum in filter paper.

One hundred micro-liter serum were dropped on to a filter paper and allowed to dry in plastic clip (in room temperature $25-27^{\circ} \mathrm{C}$ ). After the serum dried, plastic clip were closed tightly, put in to an envelope and stored in room temperature $27-33{ }^{\circ} \mathrm{C}$ for 1 week.
After storage, the filter paper were put in to an ependorf tube and $400 \mu \mathrm{L} \mathrm{ddH}_{2} \mathrm{O}$. DEPC were filled in the tube then incubated in the waterbath, $37^{\circ} \mathrm{C}$, for 1 hour. One hundred micro-liter were taken to extract the DNA with High Pure PCR-Template Preparation Kit (Roche Diagnostics, GmBH, Germany).

HBV genotype identification were done with sets of specific primers according to Naito et al ${ }^{11}$ with some modification and optimation to detect the genotype based on nucleotide difference in region pre-S1, pre$\mathrm{S} 2$ and $\mathrm{S}$ of HBV genome. Briefly, $5 \mu \mathrm{L}$ solution from DNA extraction were amplified with Faststat (Roche Diagnostics, GmBH, Germany). Primers for $1^{\text {st }}$ round PCR were P1b (sense): 5'TCA CCA TT TCT TGG GAA CAA GA 3' dan S1-2 (antisense): 5' CGA ACC ACT GAA CAA ATG G C 3'. $5 \mu \mathrm{L}$ amplicon from $1^{\text {st }}$ round PCR were put in to 2 separate tube for 2 different mix. The first mix were used primer B2 (sense): 5'GGC TCA AGT TCA GGA ACA GT 3'; BAIR (antisense): 5' CTC GCG GAG ATG GAC GAG AGT 3' ; BB1R (antisense): 5' CAG GTT GGT GAG TGA CTC GAG A 3'; BC1R (antisense): 5' GGT CCT AGG AAT CCT GAT GTT G 3' to detect genotype $\mathrm{A}, \mathrm{B}$, and $\mathrm{C}$ at DNA bands of 68 base pair (bp), $281 \mathrm{bp}$ and $122 \mathrm{bp}$, respectively. The second mix were used primer BD1 (sense): 5' GCC AAC AAG GTA GGA GCT 3'; BE1 (antisense): 5'CAC CAG AAA TCC AGA TTG GGA CCA 3'; BF1 (antisense): 5'GTT ACG GTC CAG GGT TAC CA 3'; dan B2R (antisense): 5' GGA GGC GGA TTT GCT GGC AA 3', to detect genotype D, E, dan F at DNA bands of $119 \mathrm{bp}$, $167 \mathrm{bp}$ and $97 \mathrm{bp}$, respectively.

Amplicon identification were done with 2\% Agarose gel (Agarose gel, Analytical grade, Promega) and Ethidium Bromide (Promega) in 1x TAE buffer that give fluorecence band in UV-light.

All study were carry out in Research Laboratory of Division of Hepatology, Department of Internal Medicine Medical Faculty, University of Indonesia / Cipto Mangunkusumo Hospital, Jakarta.

\section{RESULTS}

For this study, 23 sera had been collected from chronic hepatitis B (CHB) patients. All reactions had been optimized before hand. Careful and strict precaution had been implemented to avoid contaminations. In every extraction and amplification batch, negative as well as positive control were included. 
Aside from the above mentioned samples sera, we collected additional 20 sera from CHB patients with $\mathrm{HBeAg}$ positive and 29 sera from hepatoma patients.
The genotypes of these sera would be compare to the results of genotypes detected from dried serum on filter paper.

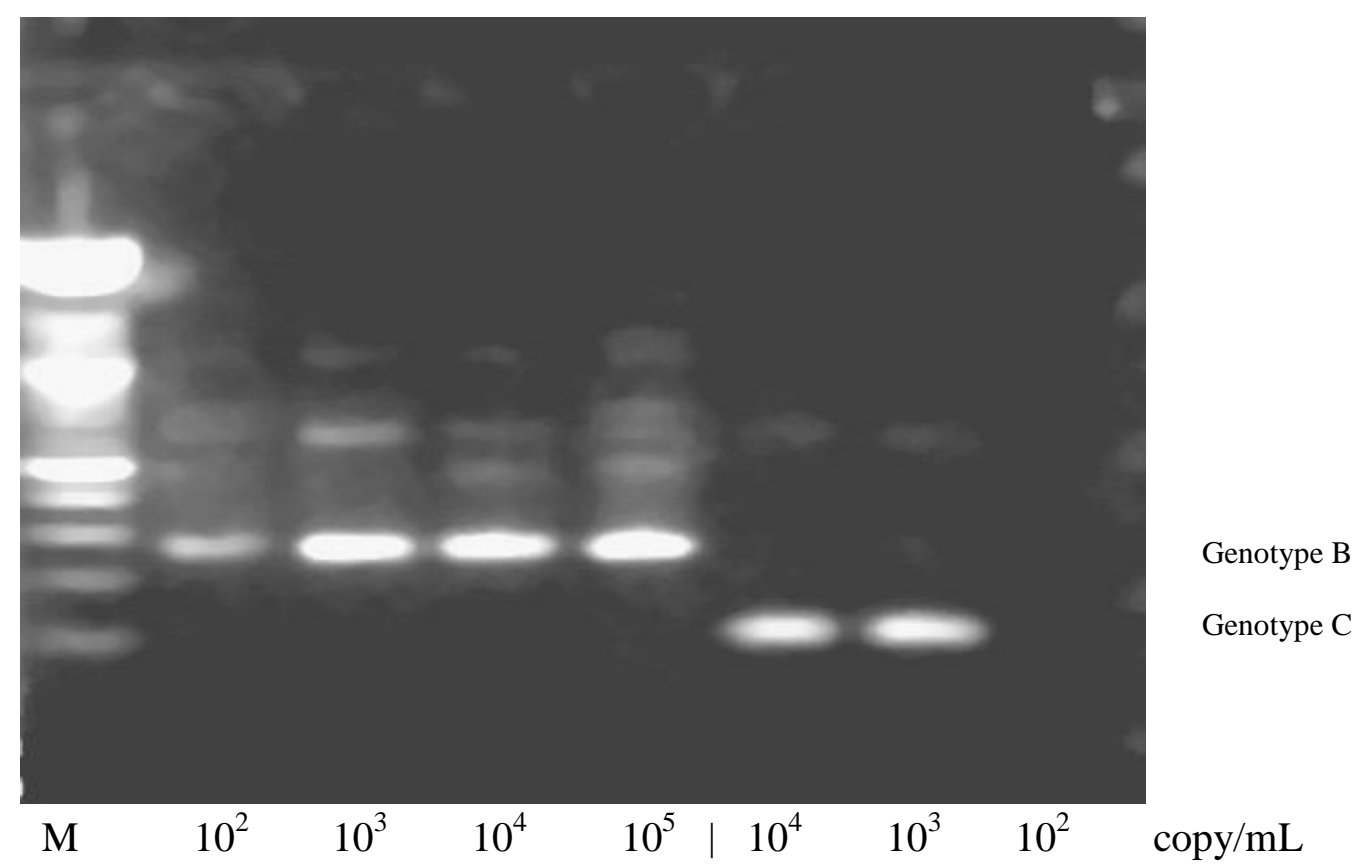

Figure 1. Genotype detection based on HBV DNA concentration of selected samples

HBV genotypes were detected in 18 out of 23 dried serum on filter paper (78.3\%).

Five samples that the genotype could not be identified were belongs to sera with HBV DNA concentration < $10^{3}$ copy/mL. Figure 1 . showed the DNA bands of genotype B were relatively weak at HBV DNA serum of $10^{2}$ copy $/ \mathrm{mL}$ compare to the bands of $10^{5}, 10^{4}$ and $10^{3}$ copy/mL. We did not have serum of genotype $\mathrm{C}$ with $10^{2}$ copy/mL but the DNA bands of $10^{5}$ and $10^{3}$ copy $/ \mathrm{mL}$ were about simlilar to the same HBV DNA concentration of genotype B. This result revealed the efficacy of genotyping from dried and stored sera would depends on HBV DNA concentration.
The genotypes of $\mathrm{CHB}-\mathrm{HBe}(+)$ sera were identified $100 \%$ (20 out of 20 samples) while genotypes from hepatoma patients were identified $82.7 \%$ (24 out of 29) samples.

Figure 2. showed the proportion of genotypes from dried sera in filter paper were 13 genotype B (72.2\%) and 5 genotype $\mathrm{C}(27.8 \%)$. Genotype $\mathrm{B}$ and $\mathrm{C}$ were also detected from $\mathrm{CHB}-\mathrm{HBe}(+)$ patients in $18(90 \%)$ and $2(10 \%)$ samples, respectively. In hepatoma patients, the majority of genotypes detected was genotype B (19 out of 25 samples, 79.2\%) and in lesser amount was genotype C (5 out of 25 samples, $20.8 \%)$. 


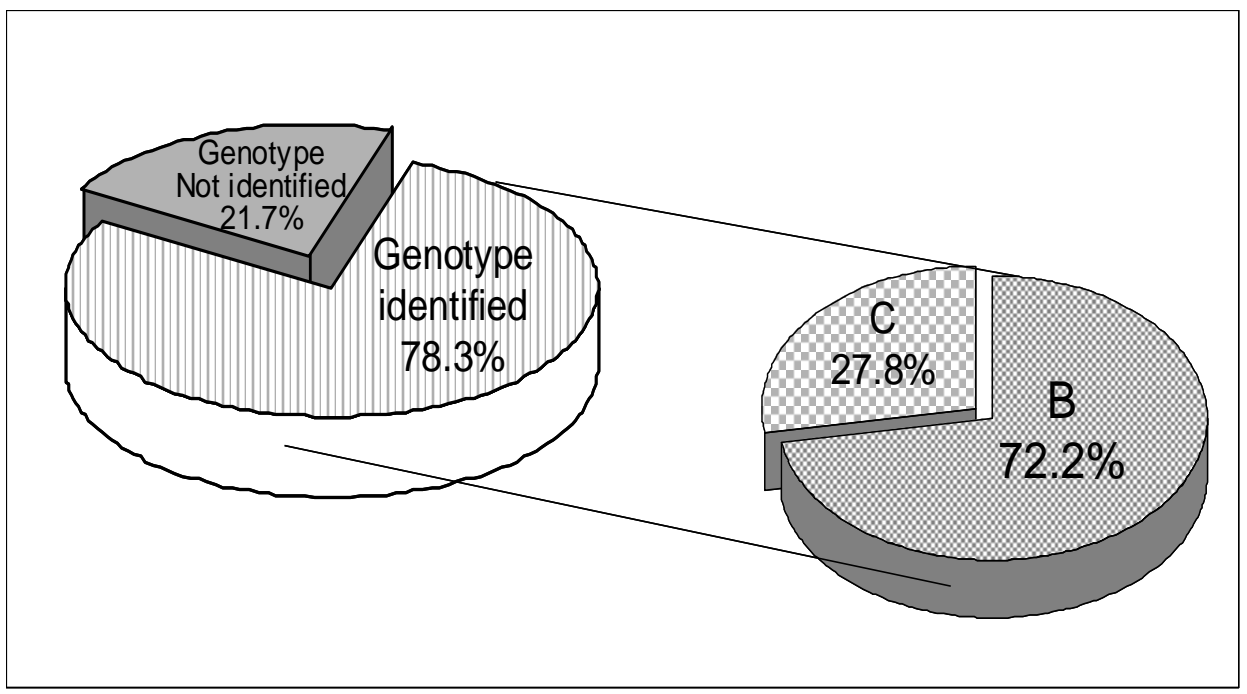

Figure 2. The proportion of dried serum samples that can be identify and proportion of genotypes from the samples

\section{DISCUSSION}

DNA has a good stability in certain conditions ${ }^{10}$ that can withstand drying. This advantage can be used to send samples in dry condition. HBV is a DNA virus ${ }^{11}$ with $3.5 \mathrm{kbp}$ and 4 overlapping, open reading frame (ORF). In serum, HBV genome formed an uncomplete, circular, double stranded DNA.

This study showed that HBV DNA in dried serum on filter paper and stored for 1 week could be used for HBV genotype determination. The efficacy of genotyping by this method depended on HBV DNA concentration in serum which will be detected reliably in the HBV DNA concentration of $>10^{3}$ copy $/ \mathrm{mL}$. In dried serum, altough HBV DNA will be degraded in storage, ${ }^{12}$ this study revealed that 1 week storage could still gave a good results for HBV genotyping. This allowed for sending a sample from remote area to a large city that has fascilities for HBV genotyping with PCR.

Although it was reported that HBV DNA could also be obtained from dropped blood on filter paper, ${ }^{7}$ detection of serum should be more consistant because there is inhibitors for PCR in whole blood that comes from the cellular components ${ }^{8}$ and it can reduced the efficacy of PCR reaction.

Genotype determination of HBV from dried serum on filter papers had been reported. ${ }^{12}$ They used Restriction Fragment Length Polymorphism (RFLP) while in this study, we use PCR with specific primers. Ideally, genotyping should be done with sequencing of HBV DNA $^{13}$ but this method is not practical. RFLP have been used for genotyping of $\mathrm{HBV}^{15}$ but this method relatively not sensitive compare to PCR. ${ }^{9} \mathrm{We}$ expected that PCR method should be more sensitive and specific compare to RFLP. In dried and stored condition, HBV DNA will be degraded, ${ }^{8}$ therefore more sensitive method should be an advantage.

Genotyping of HBV can also be done with combine method of PCR and RFLP ${ }^{6,16}$ or PCR and line probe assay (Inno-Lipa) ${ }^{17}$ but these methods may need more equipment and may be cumbersome. The use of just one method, like PCR in this study, may be more beneficial because no need to add other equipment or enzime and it can be used also for HBV DNA detection as well as genotyping which will be easier in handling of the samples.

We tried as much as possible to make samples conditions as if to be send by mail including to stored the samples in a plastic clip and closed envelope. Plastic clip were used to keep the samples in dry condition. Plastic material does not react with $\mathrm{DNA}^{10}$ and relatively easy to find in Indonesia.

In this study, good result of HBV genotyping could be done with HBV DNA concentration of $>10^{3}$ copy $/ \mathrm{mL}$. Most samples have HBV DNA concentration of more than that value, hence this method could be aplicable 
in the majority of samples. Sensitivity of HBV genotyping with sets of specific primers ${ }^{9}$ was not reported thus we must made our own measurement of sensitivity. Identification of genotype from hepatoma patients were not all successful because of low serum HBV DNA concentration in such patients. This result was not due to the unabilty of the primers to identify HBV genotype because in CHB-Hbe (+) patients where HBV DNA concentration is higher, this method could detect the genotype in all samples.

Current study revealed the genotypes of dried serum in filter paper proportionately the same with the results of reported genotype in Indonesia where genotype B is predominant, followed by genotype C. ${ }^{2,6}$ Genotype D is rarely reported in Indonesia and more prevalent in mediterranian. ${ }^{6} \mathrm{We}$ could not detect genotype $\mathrm{D}$ in our samples. This might not be due to the method that was less sensitive to this peculiar genotype but because of the variability of $\mathrm{HBV}$ genotype distribution in Indonesia. One study in East Java showed only genotype B could be detected. ${ }^{18}$ In our study other group of patients, the genotypes detected were also genotype $\mathrm{B}$ and $\mathrm{C}$ which explained the majority of HBV genotype in our population.

Genotyping system in the current study was in region preS/S of HBV genome. The variation of nucleotide in this region were reported in agreement with nucleotide sequencing, a standard method for genotyping. Although this study only used one region of $\mathrm{HBV}$ genome, there was a good chance that HBV genome still intact in dried and stored serum in filter paper that any study of HBV genome in other ORF or region could be done in the future.

In conclusion, dried serum in filter paper and stored for 1 week could be used to determined HBV genotype. Dried serum in filter paper is more practical to transport compare to serum in tube because no cold storage is needed, can not spill, lighter and small. This advantage will allow for sample transportation from remote area that does not have facilities to send the serum to large cities where HBV DNA extraction and genotyping with PCR method can be performed.

\section{REFERENCES}

1. Fattovich G, Brollo L, Giustina G et al. Natural history and prognostic factors for chronic hepatitis type B. Gut 1991;32:294-8
2. Sastrosoewignjo RI, Sandjaja B, Okamoto H. Molecular epidemiology of hepatitis B virus in Indonesia. J Gastroenterol Hepatol 1991;6:491-8.

3. Wai CT, Chu CJ, Hussain M, Lok ASF. HBV genotype is associated with better response to inteferon therapy in $\mathrm{HBeAg}(+)$ chronic hepatitis than genotype C. Hepatology 2002;36:1425-30.

4. Zolner B, Petersen J, Schafer P, Schroter M, Laufs R, Sterneck $M$ et al. Subtype-dependent response of hepatitis $B$ virus during the early phase of lamivudine treatment. Clin Infect Dis 200234:1273-7.

5. Orito E, Mizokami M, Sakugawa H, Michitaka K, Ishikawa $\mathrm{K}$, Ichida $\mathrm{T}$ et al. A case-control study for clinical and molecular biological difference between hepatitis $\mathrm{B}$ viruses of genotype B and C. Hepatolgy 2001;33:218-23.

6. Neni Nurainy. Keanegaragaman molekul virus hepatitis B dan kaitannya dengan latar belakang populasi manusia di Indonesia. Thesis Doktor Program Biomedik Pasca sarjana Fakultas Kedokteran Universitas Indonesia, 2005.

7. Gupta BP, Jayasuryan N, Jameel S, Direct detection of hepatitis B virus from dried blood spots by polymerase chain reaction amplification. J Clin Microbiology 1992; 30(8);1913-16.

8. Wang CYJ, Giambrone JJ, Smith BF. Detection of duck hepatitis B virus DNA on filter paper by PCR and SYBR green dye-based quantitative PCR. J Clin Microbiology 2002;40:2584-90.

9. Naito H, Hayashi S, Abe K. Rapid and specific genotyping system for hepatitis B virus corresponding to six major genotypes by PCR using type-specific primer. J Clin Microbiology 2001;39:362-4.

10. Raven P, Johnson GB. Understanding biology. Times Mirror/Mosby College Publishing, 1988.

11. Ganem D, Prince AM. Hepatitis B virus infection - natural history and clinical consequences. $\mathrm{N}$ Engl $\mathrm{J}$ Med 2004;350:1118-29.

12. Rodriguez-Frias J, Buti M, Schaper M, Valdes A, Martinez M, Esteban R, Guardia J. Usefulness of dried blood samples for quantification and molecular characterization of $\mathrm{HBV}$ DNA. Hepatology 2004;40(1):133-9.

13. Okamoto H, Tsuda F, Sakugawa H, Sastrosoewignjo RI, Imai M, Miyakawa $\mathrm{Y}$ et al. Typing hepatitis B virus by homology in nucleotide sequence: comparison of surface antigen subtype. J Gen Virol 1988;69:2575-83.

14. Chu CJ, Lok AS. Clinical significance of hepatitis B virus genotype. Hepatology 2002;35:1274-6.

15. Mizokami M, Nakano T, Orito E, Tanaka Y, Sakugawa H, Mukaide M, et al. Hepatitis B virus genotype assignment using rectriction fragment length polymorphism. FEBS Letters 1999;450:66-71.

16. Orito E, Ichida T, Sakugawa H, Sata M, Horiike N, Hino K, et al. Geographic distribution of hepatitis B virus (HBV) genotype in patients with chronic HBV infection in Japan. Hepatology 2001;43:590-4.

17. Grandjaques C, Pradat P, Stuyver L, Chevallier M, Chevallier P, Pichoud C, et al. Rapid detection of genotypes and mutation in the pre-core promoter and the pre-core region of hepatitis B virus genome: correlation with viral persistence and disease severity. J Hepatol 2000;33:430-9.

18. Lusida MI, Surayah, Sakugawa H, Nagano-Fujii M, Soetjipto, Mulyanto et al. Microbiol Immunol 2003;47:969-75. 
